medRxiv preprint doi: https://doi.org/10.1101/2021.03.07.21252302; this version posted March 17, 2021. The copyright holder for this preprint (which was not certified by peer review) is the author/funder, who has granted medRxiv a license to display the preprint in perpetuity.

It is made available under a CC-BY-NC-ND 4.0 International license .

\title{
Title: In vivo evaluation of the virucidal efficacy of Chlorhexidine and Povidone-iodine mouthwashes against salivary SARS-CoV-2.
}

\author{
Rola Elzein ${ }^{*}$, Fadi Abdel-Sater ${ }^{2 *}$, Soha Fakhreddine ${ }^{3}$, Pierre Abi Hanna ${ }^{3}$, Rita Feghali ${ }^{4}$, Hassan \\ Hamad $^{5}$, Fouad Ayoub 6 \\ ${ }^{1}$ Department of Pediatric Dentistry and Public Dental Health, Faculty of Dental Medicine, Lebanese University, \\ Beirut, Lebanon \\ ${ }^{2}$ Laboratory of Cancer Biology and Cellular Immunology, Department of Biological Sciences, Faculty of Sciences, \\ Lebanese University, Beirut, Lebanon \\ ${ }^{3}$ Infectious Diseases division, Rafik Hariri University Hospital, Beirut, Lebanon \\ ${ }^{4}$ Department of Laboratory Medicine, Rafik Hariri University Hospital, Beirut, Lebanon \\ ${ }^{5}$ Medical care Laboratory, Faculty of Public Health IV, Lebanese University, Zahle, Lebanon \\ ${ }^{6}$ Department of Forensic Odontology, Human Identification and Anthropology, Faculty of Dental Medicine, Lebanese \\ University, Beirut, Lebanon
}

\section{*CORRESPONDING AUTHORS:}

Rola ELZEIN; Mobile number: 009613252480; Email address: Roulaelzein@ul.edu.lb

Fadi Abdelsater; Mobile number: 009613781176; Email address: Roulaelzein @ul.edu.lb 
medRxiv preprint doi: https://doi.org/10.1101/2021.03.07.21252302; this version posted March 17, 2021. The copyright holder for this preprint (which was not certified by peer review) is the author/funder, who has granted medRxiv a license to display the preprint in perpetuity.

It is made available under a CC-BY-NC-ND 4.0 International license .

\begin{abstract}
Background. The oral cavity is potentially high-risk transmitter of COVID-19. Antimicrobial mouthrinses are used in many clinical pre procedural situations for prophylactic purposes. An evident-based investigation for an effective mouthwash solution against salivary SARS-CoV-2 is urgently required for the exposure reduction during dental procedures.
\end{abstract}

Aims. This study aimed to evaluate in vivo virucidal efficacy of 2 mouthwashes: $1 \%$ Povidoneiodine and $0.2 \%$ Chlorhexidine as a dental preprocedural oral disinfection against salivary SARSCoV-2.

Materials and Methods. In this randomized-controlled clinical trial, studied group comprised laboratory-confirmed COVID-19 positive patients through nasopharyngeal swabs. Participants were divided into 3 groups. For 30 seconds, group A gargled with 1\% Povidone-iodine, group B mouthrinsed with $0.2 \%$ Chlorhexidine and control group $\mathrm{C}$ mouthrinsed with distilled water. Saliva samples were collected before and 5 minutes after mouthwash. SARS-CoV-2 rRT-PCR was then performed for each sample. Evaluation of the efficacy was based on difference in $\mathrm{Ct}$ value. The analysis of data was carried out using GraphPad Prism version 5 for Windows. Paired t test and unpaired t test were used. A probability value of less than 0.05 was regarded as statistically significant.

Results. Sixty-one compliant participants (36 female and 25 male) with a mean age $45.3 \pm 16.7$ years-old were enrolled. A significant mean Ct value difference $(p<0.0001)$ between the paired samples in group A $(\mathrm{n}=25)$ and also in group B $(\mathrm{n}=27)(p<0.0001)$ was found. In contrast, no significant difference $(p=0.566)$ existed before and after the experiment in the control group C ( $\mathrm{n}$ =9). Moreover, a significant difference was noted between the delta $\mathrm{Ct}$ of distilled water wash and each of the 2 solutions $1 \%$ Povidone-iodine $(p=0.012)$ and Chlorhexidine $0.2 \%(p=0.0024)$. No significant difference was found between the delta $\mathrm{Ct}$ of patients using $1 \%$ Povidone-iodine and Chlorhexidine $0.2 \%$ solutions $(p=0.24)$.

Conclusion. Chlorhexidine $0.2 \%$ and $1 \%$ Povidone-iodine oral solutions are effective preprocedural mouthwashes against salivary SARS-COV-2 in dental treatments. Their use as a 
medRxiv preprint doi: https://doi.org/10.1101/2021.03.07.21252302; this version posted March 17, 2021. The copyright holder for this preprint (which was not certified by peer review) is the author/funder, who has granted medRxiv a license to display the preprint in perpetuity.

It is made available under a CC-BY-NC-ND 4.0 International license .

preventive strategy to reduce the spread of COVID-19 during dental practice should be systematically implemented.

Keywords. COVID-19; Salivary SARS-CoV-2; $1 \%$ Povidone-iodine gargle; Chlorhexidine 0.2\% mouthrinse; Dentistry; Prevention.

\section{Introduction}

Severe acute respiratory syndrome coronavirus 2 (SARS-CoV-2) is the novel member of the human coronaviruses from the Coronaviridae family and belongs to the Betacoronavirus genus. ${ }^{1}$ The subsequent corona virus disease-2019 (COVID-19), rapidly spreading worldwide, ${ }^{2}$ mostly causes respiratory disorders. ${ }^{3,4}$ The human-to-human transmission of SARS-CoV-2 essentially happens by inhalation of respiratory droplets spread by coughing or sneezing from an infected person, and by direct contact of contaminated surfaces followed by touching the nose, mouth and eyes..$^{5,6}$ The virus can even survive on various surfaces for days. ${ }^{7}$ Transmission via ocular has been shown. ${ }^{8}$ The oral cavity is potentially high-risk transmitter of COVID-19. In fact, when operating dental treatments with the high-speed handpiece, it is fundamental to use a water coolant, ${ }^{9}$ generating consequently aerosols mixed with saliva or blood. These bioaerosols, generally contaminated with microorganisms including bacteria, fungi, and viruses, float in the air then settle on the surfaces and can be transmitted to the dentists or other patients by inhalation or contact. ${ }^{10,11}$ SARS-CoV-2, was identified in saliva of infected patients. ${ }^{12}$ Furthermore, it has been reported that the main cell receptor of SARS-CoV-2, angiotensinconverting enzyme II (ACE2), is extremely expressed on the mucosa of the oral cavity and particularly in the epithelial cells of the tongue. ${ }^{13}$ Therefore, it is crucial for dental practitioners to install preventive strategies to avoid the COVID-19 infection by focusing not only on patient 
medRxiv preprint doi: https://doi.org/10.1101/2021.03.07.21252302; this version posted March 17, 2021. The copyright holder for this preprint (which was not certified by peer review) is the author/funder, who has granted medRxiv a license to display the preprint in perpetuity.

It is made available under a CC-BY-NC-ND 4.0 International license .

placement, hand hygiene, all personal protective equipment, caution in performing aerosolgenerating procedures but also on patient's pre-procedural antiseptic mouthrinse. ${ }^{14,15}$ In fact, antimicrobial mouthrinses are an important part of oral care. Such solutions are used in many clinical pre procedural situations for prophylactic purposes. ${ }^{16,17}$ Preprocedural oral solution is one of the most effective methods of reducing the amount of microorganisms in oral aerosols. ${ }^{18,19}$ In addition, gargling is also assumed to produce favorable effects through removal of oral and pharyngeal protease that helps viral replication.$^{20}$

Thus, an investigation for an effective mouthrinse against COVID-19 is urgently required for the control of oral and respiratory tract infection and for the exposure reduction during dental procedures.

In the literature, it was reported that a pre-procedural $0.12 \%$ Chlorhexidine mouth rinse can reduce the microbial load of saliva. ${ }^{21}$ A meta-analysis showed that the use of preprocedural mouth rinse, including Chlorhexidine, essential oils, and cetylpyridinium chloride, resulted in a mean reduction of $68.4 \%$ colony-forming units in dental aerosol. ${ }^{22}$ Although the effect of Chlorhexidine gluconate on human coronavirus is unknown but it is effective against many respiratory viruses, like herpes and HIV. ${ }^{23}$ On the other hand, Povidone-iodine is a broad-spectrum antimicrobial that has been used in infection control and prevention for over 60 years and is available in various preparations for use as a disinfectant for the skin, hands and mucosal surfaces, as well as for wound treatment and eye applications. ${ }^{24}$ Povidone-iodine has well-established general antimicrobial activity, demonstrating in vitro efficacy against wide range of enveloped and nonenveloped viruses. ${ }^{25-27}$ Recent in vitro study has demonstrated rapid virucidal its products activity against MERSCoV. ${ }^{28,29}$ The benefit of gargling with Povidone-iodine has also already been noted in Japanese clinical respiratory guidelines. ${ }^{30}$ 
medRxiv preprint doi: https://doi.org/10.1101/2021.03.07.21252302; this version posted March 17, 2021. The copyright holder for this preprint (which was not certified by peer review) is the author/funder, who has granted medRxiv a license to display the preprint in perpetuity.

It is made available under a CC-BY-NC-ND 4.0 International license .

This study, besides of being an additional research concerning the Consistency of detection of SARS-CoV-2 in saliva from the Lebanese experience, aimed mainly to evaluate in vivo virucidal efficacy of 2 mouthrinses: $1 \%$ Povidone-iodine and $0.2 \%$ Chlorhexidine as a dental preprocedural oral disinfection against salivary SARS-CoV-2.

\section{Materials and methods.}

Ethical approval. Ethical clear of this research was delivered from the Lebanese University Institutional Review Board (\#CUER 13-2020). The study was conducted in accordance with the 1964 Helsinki declaration and its later amendments or comparable ethical standards. All participants were informed about the study and gave their consent. It was conducted between June and Septembre 2020 at the isolation ward of Rafik Hariri University Hospital (RHUH) of Beirut for sampling and in the Laboratory of Cancer Biology and Cellular Immunology, COVID-19 Unit, Faculty of Sciences, Lebanese University for viral PCR tests.

Trial design. This study was a parallel group, quadruple blind-randomized-placebo-controlled clinical trial with an add on laboratory based study. Patients, intervention supervisor, laboratory technicians and the data collection subject were blinded. The groups were labelled as A, B and C. The codes of the intervention were only revealed at the end of study.

Participants. A non-probability, purposive sampling technique was adopted. Studied group comprised, laboratory-confirmed COVID-19 positive patients, through nasopharyngeal swabs. The lapse of time between COVID-19 diagnosis and inclusion in the study ranged from zero to two days. Were excluded cases indicated for intubation or mechanical ventilation and patients who declined consent. 
medRxiv preprint doi: https://doi.org/10.1101/2021.03.07.21252302; this version posted March 17, 2021. The copyright holder for this preprint (which was not certified by peer review) is the author/funder, who has granted medRxiv a license to display the preprint in perpetuity.

It is made available under a CC-BY-NC-ND 4.0 International license .

Solution preparation. $15 \mathrm{ml}$ of each undiluted mouthwash solution were previously poured into a sterile cup within a Biosafety cabinet (Topair system) in the Laboratory of Cancer Biology and Cellular Immunology, Faculty of Sciences, Lebanese University with respect to the manufacturer recommendations for each solution. The containers were marked as $\mathrm{A}, \mathrm{B}$ or $\mathrm{C}$, and then delivered to RHUH to accomplish the sampling. Solution A referred to $1 \%$ Povidone-iodine, B for $0.2 \%$ Chlorhexidine and $\mathrm{C}$ for distilled water as a placebo treatment.

Sampling. Participants were randomly divided into the three groups. The same trained operator explained, provided and supervised the sampling in patient's room with respect to COVID-19 infection control. Sampling was performed by the patients themselves in the early morning on empty stomach and before brushing teeth. First, participants were asked to cough out saliva from throat $(2 \mathrm{ml})$, into a first sterile container. Next, group A participants $(n=33)$ were invited to gargle for 30 seconds with solution A, group B $(n=33)$ to mouthrinse for 30 seconds with solution B and group $\mathrm{C}(\mathrm{n}=11)$ to mouthrinse for 30 seconds with solution $\mathrm{C}$ and then to spit the solution. Five minutes later, saliva collections were done again in a second sterile container. Each cup held patient's name and the date of saliva collection while contaminated waste was appropriately discarded. Each collected sample was then inserted into separated tubes containing $2 \mathrm{~mL}$ of the virus transport medium (VTM) and transported to the COVID unit Laboratory in the Lebanese university for PCR processing.

SARS-CoV-2 rRT-PCR. The presence of SARS-CoV-2 was confirmed by real-time reverse transcriptase polymerase chain reaction (RT-PCR). $200 \mu \mathrm{L}$ of VTM was used for RNA purification. RNA was extracted from the clinical samples on Kingfisher flex purification system Thermo Fisher using MagMAX ${ }^{\mathrm{TM}}$ Viral/Pathogen Nucleic Acid Isolation Kit (thermos fisher). Reactions were performed in $20 \mu \mathrm{L}$ final volume reaction containing $5 \mu \mathrm{L}$ of extracted RNA, rRT- 
medRxiv preprint doi: https://doi.org/10.1101/2021.03.07.21252302; this version posted March 17, 2021. The copyright holder for this preprint (which was not certified by peer review) is the author/funder, who has granted medRxiv a license to display the preprint in perpetuity.

It is made available under a CC-BY-NC-ND 4.0 International license .

PCR was performed using CFX96 real-time PCR detection system (Bio-Rad, Hercules, CA, USA) and Bosphore Novel Coronavirus (2019-nCoV) PCR Detection Kit v4 (Anatolia, Turkey), which targeted the RdRP, $\mathrm{N}$ and $\mathrm{E}$ genes of SARS-CoV-2. In this assay, a RNase $\mathrm{P}$ gene region is used as an endogenous internal control for the analysis of biological samples. It is normally used to ensure the quality of the test, at extraction and PCR levels and to exclude the false negative results. Thus, in order to evaluate possible variability in the amount of material retrieved from saliva specimen before and after mouth wash we utilized RNase $\mathrm{P}$ as reference gene to normalize the input data.

To compare the paired samples before and after mouth wash, we calculated a $\mathrm{Ct}$ value modified according to the ratio of sample RNase P and mean RNase P Ct values. ${ }^{31}$

$\underline{\text { sample SarsCoV2 Ct value x sample RNaseP Ct }}$ mean RNaseP Ct value

Statistical Analysis. The analysis of data was carried out using GraphPad Prism version 5 for Windows (GraphPad Software, La Jolla California USA, www.graphpad.com). Differences between the means of the two matched groups were explored using Paired t test. The means of the two independent Groups were compared by using the Unpaired t test. A probability value of less than 0.05 was regarded as statistically significant. 
medRxiv preprint doi: https://doi.org/10.1101/2021.03.07.21252302; this version posted March 17, 2021. The copyright holder for this preprint (which was not certified by peer review) is the author/funder, who has granted medRxiv a license to display the preprint in perpetuity.

It is made available under a CC-BY-NC-ND 4.0 International license .

\section{Results}

In total, while 77 patients were eligible for the study, 16 were excluded resulting in 61 compliant participants (Figure 1). Among the final study group, 36 (59.1\%) were female and 25 (40.9\%) were male. The mean age of all patients was $45.3 \pm 16.7$ with an age range between 17 and 85 years old. The description of each group is mentioned in table 1.

The mean Ct value of human RNaseP in saliva samples before mouthwash was $25.41 \pm 2.5$ [18.432.21]. Among the specimens tested, 72.4\% had RNaseP Ct values below 27, 20.7\% between 27 and 30, and 7.9\% between 30 and 32.2. The mean $\mathrm{Ct}$ value of human RNaseP in saliva samples after mouthwash was $26 \pm 2.72$ [19.49-32.5]. No significant difference was found between the mean $\mathrm{Ct}$ values of human RNaseP in the 2 groups $(p=0.332)$.

The expression of the SARS-CoV-2 target genes (RdRp, E and N) used was approximately the same in each tested sample. To simplify our analysis, we presented the results with RdRp. For this gene the mean Ct value was $28.9 \pm 5.5$ (Median 29.9 [16.45-38.16]) in salivary pre-wash samples. After normalization, the SARS-CoV-2 mean Ct value was $28.3 \pm 6.3$.

Our results showed a significant mean difference between the paired samples before $(29.88 \pm 6.2$; median 30.75) and after mouthwash (34.36 \pm 6.3 ; median 34.19) with $1 \%$ Povidone-iodine ( $p<$ 0.0001). After mouthwash, the difference between means was 4.45 (Figure 2A). In addition, a higher significant difference of means was found in paired samples using Chlorhexidine 0.2\% ( $p$ $<0.0001)$. The mean $\mathrm{Ct}$ increased 5.69 after mouthwash. The mean $\mathrm{Ct}$ of pre and post mouthwash was respectively $27.69 \pm 7.16$ (median 27.11) and $33.9 \pm 7.08$ (median 33.13) (Figure 2B). In contrast, no significant difference was found in the control group using the distilled water as mouthwash solution as shown in figure $2 \mathrm{C}(p=0.566)$. Moreover, the comparison of the delta $\mathrm{Ct}$ showed a significant difference between distilled water wash and each of the 2 solutions Povidoneiodine and Chlorhexidine $0.2 \%$ ( $p$ value 0.012 and 0.0024 respectively). No significant difference 
medRxiv preprint doi: https://doi.org/10.1101/2021.03.07.21252302; this version posted March 17, 2021. The copyright holder for this preprint (which was not certified by peer review) is the author/funder, who has granted medRxiv a license to display the preprint in perpetuity.

It is made available under a CC-BY-NC-ND 4.0 International license .

was found between the delta $\mathrm{Ct}$ of patients using $1 \%$ Povidone-iodine and Chlorhexidine $0.2 \%$ solutions $(p=0.24)$ (Figure 3$)$. We noted that $\mathrm{Ct}$ values are considered inversely related to viral load and may serve as an indirect method of arbitrarily quantifying the viral load in the sample.

\section{Discussion}

With the novel COVID-19 pandemic, dental care practitioners were in urge to develop quick infection control policies. ${ }^{32}$ So far, clinical implementation of new concepts was mainly based on recommendations without being evident based. Particularly, different pre-procedural mouthwash solutions to minimize the SARS-CoV-2 transmission during dental treatment were recommended by some dental specialist societies. ${ }^{33-35}$ Despite lack of any clinical data supporting the virucidal effects of mouthwash solutions against SARS-CoV-2, many propositions were adopted in reviews discussing the COVID-19 preventive measurements in Dentistry. ${ }^{36-41}$ A recent in-vitro study tested the effect of the following mouth rinses on cell viability: hydrogen peroxide, povidone-iodine, chlorhexidine gluconate and essential oils with alcohol. The experiments found that mouth rinses can significantly reduce virus infectivity, suggesting a potential benefit for reducing SARS-CoV2 spread. The study concluded that the clinical investigation of antiviral effects of mouth rinses is needed for proving their potential to reduce the virus spread. ${ }^{42}$

For our knowledge this current in vivo study is the first large scale controlled-clinical trial testing the efficacy of $1 \%$ Povidone-iodine oral gargle and $0.2 \%$ Chlorhexidine oral mouthwash on salivary SARS-CoV-2 virus of positive tested patients.

This study comprised 61 compliant COVID-19 positive subjects. During sampling recruitment, the non-detection of SARS-CoV-2 in nasopharyngeal samples of four hospitalized positive patients could be explained by the fact that the nucleic acid test results of a significant proportion 
medRxiv preprint doi: https://doi.org/10.1101/2021.03.07.21252302; this version posted March 17, 2021. The copyright holder for this preprint (which was not certified by peer review) is the author/funder, who has granted medRxiv a license to display the preprint in perpetuity. It is made available under a CC-BY-NC-ND 4.0 International license .

of patients are "false negative". ${ }^{43}$ For ethical issues, mainly avoiding the patient subsequent discomfort, we preferred to exclude these participants instead of repeating the nasopharyngeal swab test for a clinical trial purpose.

In placebo-controlled clinical trials with "very ill” subjects it is unethical to assign equal subjects to each arm and it is preferable to have more subjects in test group compared to the control one. In such cases, sample size is adjusted if clear and clinically meaningful inputs on some points are available prior to working on sample size estimation. ${ }^{44}$ As COVID-19 is a recently emerging pandemic without previous related data in addition to its critical incompletely explored status, we considered that our sample size for the test and control groups were legible.

Saliva sampling was self-performed by the patients to reduce the risk of nosocomial SARS-CoV2 transmission to health care providers. ${ }^{12,45}$ A lapse of time of 5 minutes between mouthrinsing or gargling and second saliva collection was chosen conforming to the real procedure at dental clinic: during dental appointment, it takes usually few minutes between the patient's preprocedural mouthwash and the commencement of the treatment.

This study firstly revealed the consistency of the detection of SARS-CoV-2 in saliva since the virus was detected in the salivary samples of 61 out of 66 patients. This result is in accordance with other studies. ${ }^{12,46,47}$ In fact, using saliva specimens for the diagnosis of COVID-19 has many advantages like avoiding invasive procedures, contributing to the decrease of the risk of nosocomial COVID-19 transmission, usefulness for screening of a large number of individuals with less time consuming and in situations in which nasopharyngeal specimen collection may be contraindicated. $^{12}$ However, further studies comparing SARS-CoV-2 viral load between saliva and nasopharyngeal samples collected at the same time for each COVID-19 tested patient are required for a better assessment for the use of saliva as a diagnosis tool for COVID-19. 
medRxiv preprint doi: https://doi.org/10.1101/2021.03.07.21252302; this version posted March 17, 2021. The copyright holder for this preprint (which was not certified by peer review) is the author/funder, who has granted medRxiv a license to display the preprint in perpetuity. It is made available under a CC-BY-NC-ND 4.0 International license .

Moreover, our results showed that a 1\% Povidone-iodine gargle reduces significantly the intraoral viral load in SARS-CoV-2-positive subjects. Our results are similar to another in-vivo study where the authors analyzed the impact of a mouthwash with Povidone-iodine on the salivary viral load of SARS-CoV-2 in 4 patients with COVID-19 and found that in 2 of the 4 participants, the gargle solution resulted in a significant drop in viral load, which remained for at least 3 h. ${ }^{48}$ Frank et al. (2020) found that Povidone-iodine can safely be used in the mouth at concentrations up to $2.5 \%$ for up to 5 months because it rapidly inactivates coronaviruses, including SARS and MERS, even when applied for as little as 15 seconds. ${ }^{49}$ The same authors were optimistic about the inactivation of SARS-CoV-2 by Povidone-iodine, and called for in vitro efficacy demonstration. Mady et al. (2020) proposed the use of oral/oropharyngeal wash with $10 \mathrm{~mL}$ of $0.5 \%$ aqueous Povidone-iodine solution in addition to nasal irrigation of $240 \mathrm{~mL}$ of $0.4 \%$ of the same antiseptic solution for patients and healthcare providers as a public health intervention for COVID-19. ${ }^{50}$ Suresh et al. (2020) proposed also a pioneer description in anesthesia practice on the use of preoperative Povidone-iodine gargles in COVID-19 cases to mitigate the chain of spread of COVID-19 through cross-infection among health care workers. ${ }^{51}$ In addition, Brida et al. (2020) investigated the invitro optimal contact time and concentration for virucidal activity of $0.5 \%, 1 \%$, and $1.5 \%$ oral solution of povidone-iodine against SARS-CoV-2 and found that the efficacy was present at the lowest concentration of $0.5 \%$ Povidone-iodine and at the lowest contact time of 15 seconds and mentioned that, therefore, preprocedural rinsing with diluted Povidone-iodine in the range of $0.5 \%$ to $1.5 \%$ may be preferred over hydrogen peroxide during the COVID-19 pandemic. $^{52}$ Pelletier et al. (2020) found that concentrations $1 \%$ to $5 \%$ of Povidone-iodine nasal antiseptics and oral rinse antiseptics completely inactivated the SARS-CoV-2 after 60-second exposure times on SARSCoV-2 infected Vero 76 cell. ${ }^{53}$ On the other hand, Chorney et al. (2020) called for further research 
medRxiv preprint doi: https://doi.org/10.1101/2021.03.07.21252302; this version posted March 17, 2021. The copyright holder for this preprint (which was not certified by peer review) is the author/funder, who has granted medRxiv a license to display the preprint in perpetuity.

It is made available under a CC-BY-NC-ND 4.0 International license .

prior to strongly recommending Povidone-iodine use in preparation for nasal, oral or pharyngeal surgery in children. ${ }^{54}$

In addition, preprocedural mouthrinse with $0.2 \%$ Chlorhexidine showed in our study a significant efficacy against SARS-CoV-2. Our results are in accordance with those of Yoon et al. (2020) who found, in a clinical trial on 2 patients, that Chlorhexidine mouthwash was effective in reducing the SARS-CoV-2 viral load in the saliva for a short-term period. ${ }^{55}$ Meister et al. (2020) found while using Vero E6 cells that different SARS-CoV-2 strains can be efficiently inactivated with Chlorhexidine and other commercially available oral rinses and recommended further analysis during clinical studies to assess the in vivo effects of the oral solutions. Chlorhexidine has been suggested to reduce the viral transmission via aerosols. ${ }^{56}$ Although its action against this virus remains controversial but if the results are confirmed by other clinical trials, Chlorhexidine mouthrinse could help to prevent the spread of SARS-CoV-2. ${ }^{57}$

Although both solutions proved significant efficacy against salivary SARS-CoV-2, $0.2 \%$ Chlorhexidine showed non-significantly more efficiency on reducing the salivary viral load than $1 \%$ povidone iodine. Distilled water had no effect on viral load. The absence of placebo effect confirmed the effectiveness of the proposed disinfectant mouthwash solutions on salivary SARSCOV-2.

\section{Conclusion}

0.2\% Chlorhexidine and $1 \%$ Povidone-iodine oral solutions are effective preprocedural mouthwashes against SARS-COV-2 in dental treatments. Their use as a preventive strategy to reduce the spread of COVID-19 should be systematically implemented in Dentistry as in various 
medRxiv preprint doi: https://doi.org/10.1101/2021.03.07.21252302; this version posted March 17, 2021. The copyright holder for this preprint (which was not certified by peer review) is the author/funder, who has granted medRxiv a license to display the preprint in perpetuity.

It is made available under a CC-BY-NC-ND 4.0 International license .

health care services. Further studies including the length of their effectiveness over the time are required for an accurate prescription against SARS-COV-2.

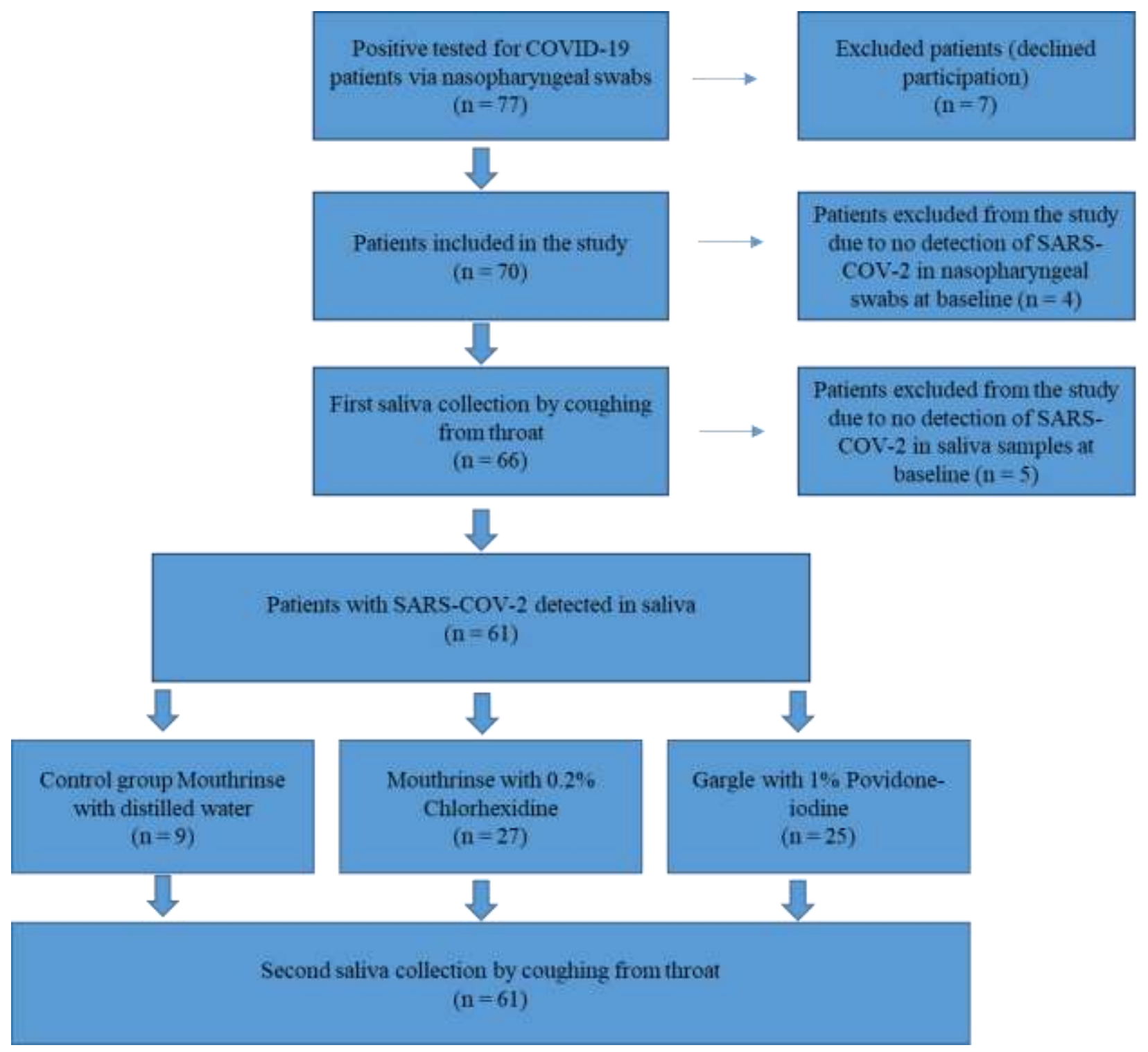

Figure 1. Flow diagram showing the enrolment process of participants in the study. 
medRxiv preprint doi: https://doi.org/10.1101/2021.03.07.21252302; this version posted March 17, 2021. The copyright holder for this preprint (which was not certified by peer review) is the author/funder, who has granted medRxiv a license to display the preprint in perpetuity.

\section{It is made available under a CC-BY-NC-ND 4.0 International license .}

\begin{tabular}{|c|c|c|c|c|}
\hline \multirow{2}{*}{ Participants } & \multicolumn{2}{|c|}{ Age years } & \multicolumn{2}{c|}{ Gender } \\
\cline { 2 - 5 } & $\begin{array}{c}\text { Median (range) } \\
\text { (years) }\end{array}$ & $\begin{array}{c}\text { Mean } \pm \text { SD } \\
\text { (years) }\end{array}$ & $\begin{array}{c}\text { Female } \\
\mathrm{N}(\%)\end{array}$ & Male \\
\hline $\begin{array}{c}\text { All patients } \\
\mathrm{N}=61\end{array}$ & $43(17-85)$ & $45.3 \pm 16.7$ & $36(59.1 \%)$ & $25(40.9 \%)$ \\
\hline $\begin{array}{c}\text { Distilled water group } \\
\mathrm{N}=9\end{array}$ & $56(21-85)$ & $57.2 \pm 22.5$ & $7(77.8 \%)$ & $2(22.2 \%)$ \\
\hline $\begin{array}{c}\text { Povidone iodine 1\% group } \\
\mathrm{N}=27\end{array}$ & $40(17-63)$ & $39.9 \pm 14.2$ & $14(51.8 \%)$ & $13(48.2 \%)$ \\
\hline $\begin{array}{c}\text { Chlorhexidine 0.2\% group } \\
\mathrm{N}=25\end{array}$ & $51(25-84)$ & $47 \pm 15.4$ & $15(60 \%)$ & $10(40 \%)$ \\
\hline
\end{tabular}

Table 1. Description of the study population. 


\section{A- Povidone-iodine 1\%}

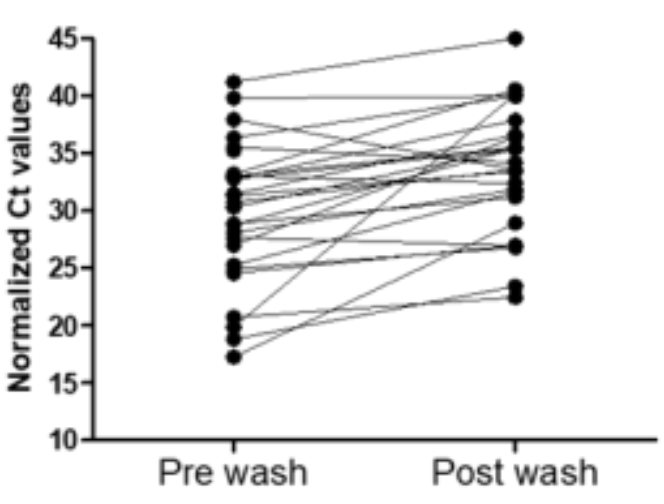

\section{B- Chlorhexidine $0.2 \%$}

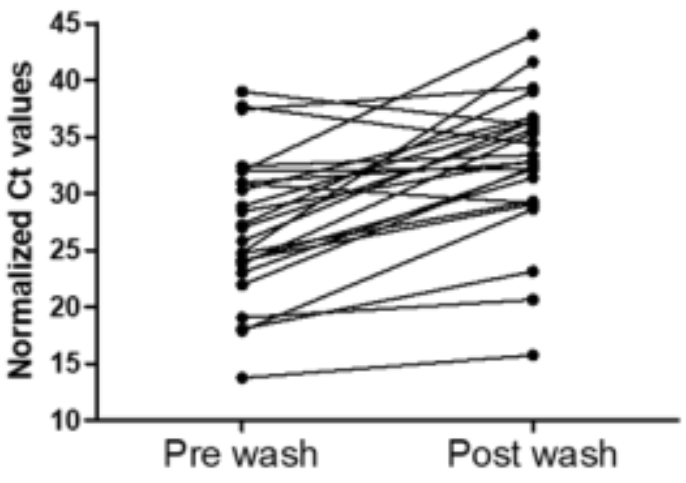

C- Distilled water

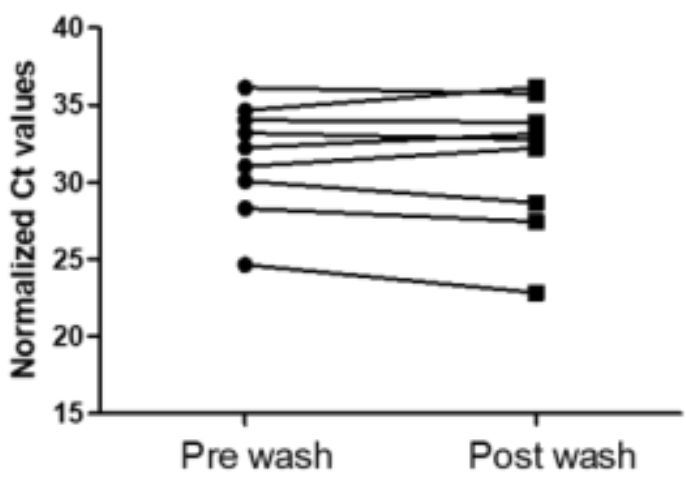

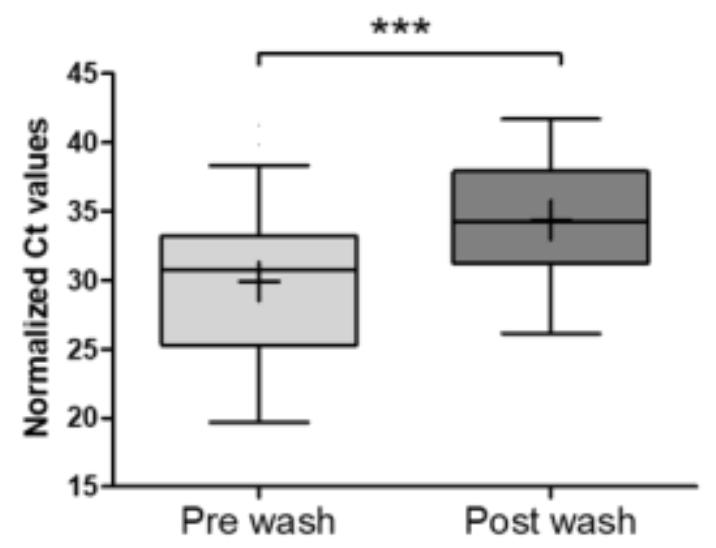
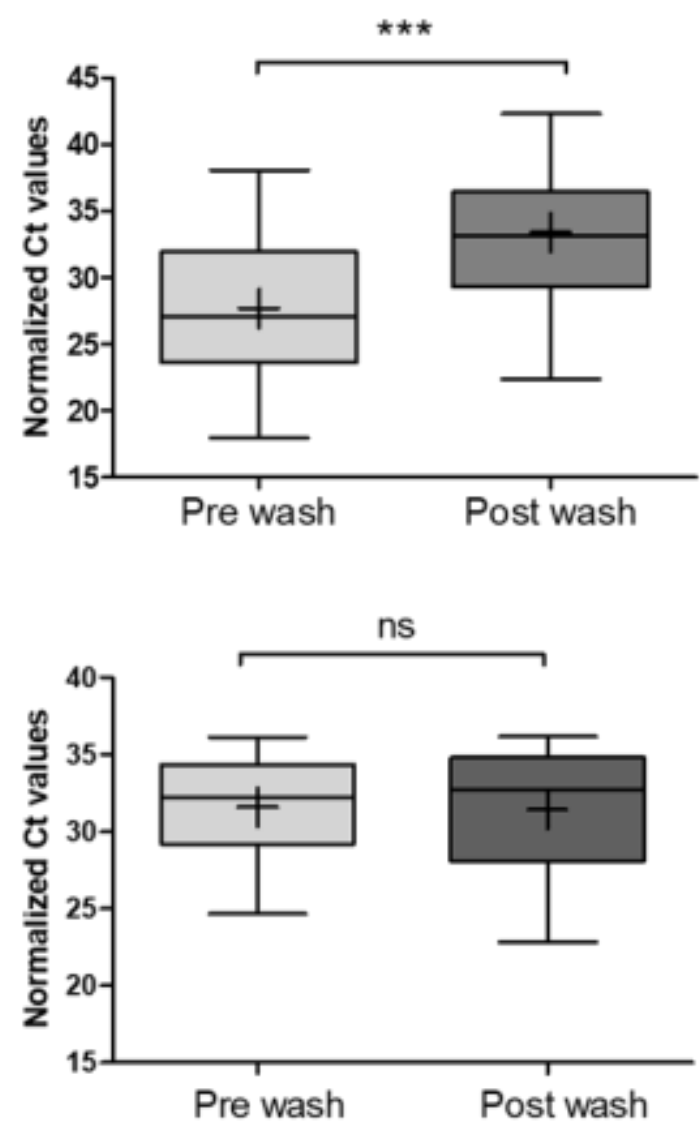

Figure 2. Normalized threshold cycle $(\mathrm{Ct})$ values for matched pre and post mouthwash salivary specimens. The Ct values of $R d R p$ obtained with RT-PCR that were detected in salivary specimens before and after mouthwash and normalized to the internal control RNAseP endogenous human gene. (A) $1 \%$ Povidoneiodine $(\mathrm{n}=25)$, (B) Chlorhexidine $0.2 \%(\mathrm{n}=27)$ and $(\mathrm{C})$ distilled water $(\mathrm{n}=9)$ were used as mouthwash solutions. The before-after graph shows the changes of $\mathrm{Ct}$ after mouth wash for each patient. The box plots show the medians (middle line) and the first and third quartiles (boxes). The mean is marked by a plus sign inside the box. Paired Groups were compared by using the Paired t test. ***Indicates a p-value $\leq 0.0001$, ns indicates no significant difference $(p>0.05)$. 
medRxiv preprint doi: https://doi.org/10.1101/2021.03.07.21252302; this version posted March 17, 2021. The copyright holder for this preprint (which was not certified by peer review) is the author/funder, who has granted medRxiv a license to display the preprint in perpetuity. It is made available under a CC-BY-NC-ND 4.0 International license .

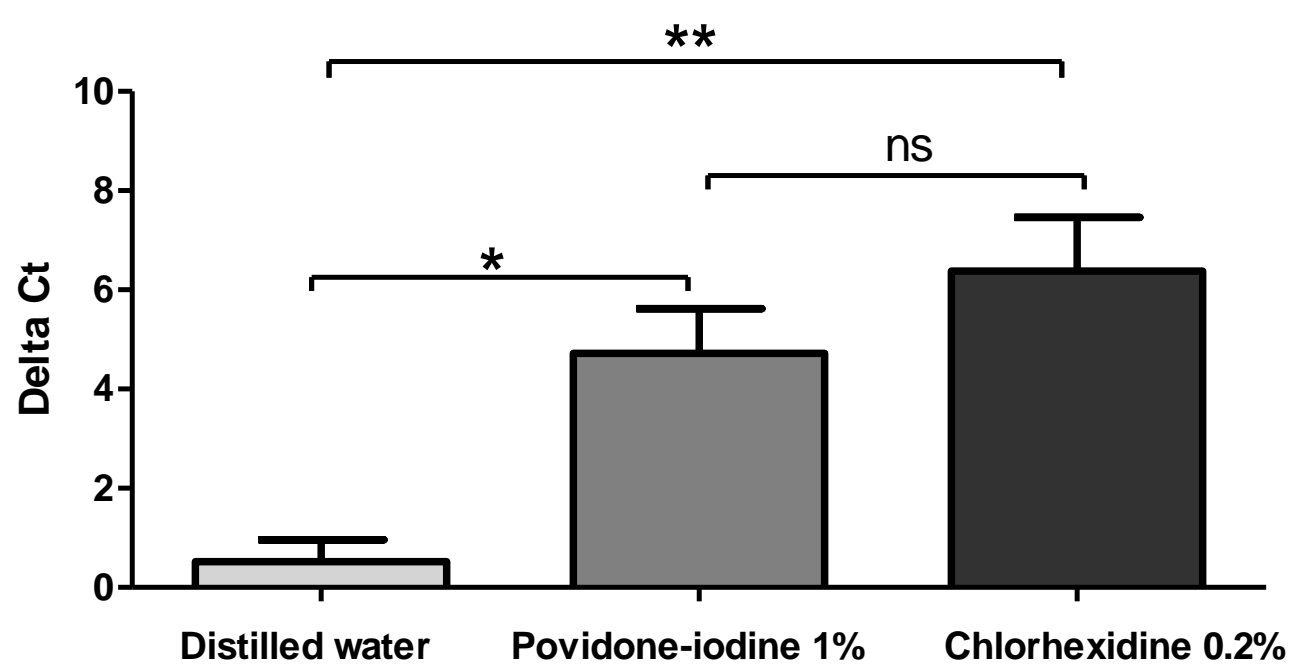

Figure 3. Comparison of Delta $\mathrm{Ct}$ mean between the mouth wash solutions. Delta $\mathrm{Ct}$ were calculated as follow: normalized $\mathrm{Ct}$ value post mouthwash minus normalized $\mathrm{Ct}$ value pre mouthwash. Groups were compared by using the Unpaired t test. Peak values are reported as mean $+/-$ SD. Significant differences between means are indicated by $*(p<0.05)$, $* *(p<0.01)$, ns indicates no significant difference $(p>0.05)$.

Funding: This work was supported by the Lebanese University. 
medRxiv preprint doi: https://doi.org/10.1101/2021.03.07.21252302; this version posted March 17, 2021. The copyright holder for this preprint (which was not certified by peer review) is the author/funder, who has granted medRxiv a license to display the preprint in perpetuity.

It is made available under a CC-BY-NC-ND 4.0 International license .

\section{REFERENCES}

1- Zhu N, Zhang D, Wang W, et al. A Novel Coronavirus from Patients with Pneumonia in China, 2019. N Engl J Med. 2020;382(8):727-733. doi:10.1056/NEJMoa2001017

2- WHO Coronavirus disease 2019 (COVID-19) situation reports. https://www.who.int/emergencies/diseases/novel-coronavirus-2019/situation-reports

3- Wang D, Hu B, Hu C, et al. Clinical Characteristics of 138 Hospitalized Patients With 2019 Novel Coronavirus-Infected Pneumonia in Wuhan, China. JAMA. 2020;323(11):10611069. doi:10.1001/jama.2020.1585

4- Huang C, Wang Y, Li X, et al. Clinical features of patients infected with 2019 novel coronavirus in Wuhan, China [published correction appears in Lancet. 2020 Jan 30]. Lancet. 2020;395(10223):497-506. doi:10.1016/S0140-6736(20)30183-5

5- Han Y, Yang H. The transmission and diagnosis of 2019 novel coronavirus infection disease (COVID-19): A Chinese perspective. J Med Virol. 2020;92(6):639-644. doi:10.1002/jmv.25749

6- Rothan HA, Byrareddy SN. The epidemiology and pathogenesis of coronavirus disease (COVID-19) outbreak. J Autoimmun. 2020;109:102433. doi:10.1016/j.jaut.2020.102433

7- Kampf G, Todt D, Pfaender S, Steinmann E. Persistence of coronaviruses on inanimate surfaces and their inactivation with biocidal agents [published correction appears in J Hosp Infect. 2020 Jun 17;:]. $J$ Hosp Infect. 2020;104(3):246-251. doi:10.1016/j.jhin.2020.01.022

8- Lu CW, Liu XF, Jia ZF. 2019-nCoV transmission through the ocular surface must not be ignored. Lancet. 2020;395(10224):e39. doi:10.1016/S0140-6736(20)30313-5

9- Farah RI. Effect of cooling water temperature on the temperature changes in pulp chamber and at handpiece head during high-speed tooth preparation. Restor Dent Endod. 2018;44(1):e3. Published 2018 Dec 24. doi:10.5395/rde.2019.44.e3

10-Grenier D. Quantitative analysis of bacterial aerosols in two different dental clinic environments. Appl Environ Microbiol. 1995;61(8):3165-3168. doi:10.1128/AEM.61.8.3165-3168.1995 
medRxiv preprint doi: https://doi.org/10.1101/2021.03.07.21252302; this version posted March 17, 2021. The copyright holder for this preprint (which was not certified by peer review) is the author/funder, who has granted medRxiv a license to display the preprint in perpetuity. It is made available under a CC-BY-NC-ND 4.0 International license .

11-Jones RM, Brosseau LM. Aerosol transmission of infectious disease. J Occup Environ Med. 2015;57(5):501-508. doi:10.1097/JOM.0000000000000448

12-To KK, Tsang OT, Yip CC, et al. Consistent Detection of 2019 Novel Coronavirus in Saliva. Clin Infect Dis. 2020;71(15):841-843. doi:10.1093/cid/ciaa149

13-Xu H, Zhong L, Deng J, et al. High expression of ACE2 receptor of 2019-nCoV on the epithelial cells of oral mucosa. Int J Oral Sci. 2020;12(1):8. Published 2020 Feb 24. doi:10.1038/s41368-020-0074-X

14-Li RW, Leung KW, Sun FC, Samaranayake LP. Severe acute respiratory syndrome (SARS) and the GDP. Part II: implications for GDPs. Br Dent J. 2004;197(3):130-134. doi:10.1038/sj.bdj.4811522

15-Ge ZY, Yang LM, Xia JJ, Fu XH, Zhang YZ. Possible aerosol transmission of COVID-19 and special precautions in dentistry. J Zhejiang Univ Sci B. 2020;21(5):361-368. doi:10.1631/jzus.B2010010

16-Harrel SK, Molinari J. Aerosols and splatter in dentistry: a brief review of the literature and infection control implications. J Am Dent Assoc. 2004;135(4):429-437. doi:10.14219/jada.archive.2004.0207

17-Klyn SL, Cummings DE, Richardson BW, Davis RD. Reduction of bacteria-containing spray produced during ultrasonic scaling. Gen Dent. 2001;49(6):648-652.

18-Sawhney A, Venugopal S, Babu GR, et al. Aerosols how dangerous they are in clinical practice. J Clin Diagn Res. 2015;9(4):ZC52-ZC57. doi:10.7860/JCDR/2015/12038.5835

19-Feres M, Figueiredo LC, Faveri M, Stewart B, de Vizio W. The effectiveness of a preprocedural mouthrinse containing cetylpyridinium chloride in reducing bacteria in the dental office. $J \quad A m \quad$ Dent Assoc. 2010;141(4):415-422. doi:10.14219/jada.archive.2010.0193

20-Kitamura T, Satomura K, Kawamura T, et al. Can we prevent influenza-like illnesses by gargling?. Intern Med. 2007;46(18):1623-1624. doi:10.2169/internalmedicine.46.0104 
medRxiv preprint doi: https://doi.org/10.1101/2021.03.07.21252302; this version posted March 17, 2021. The copyright holder for this preprint (which was not certified by peer review) is the author/funder, who has granted medRxiv a license to display the preprint in perpetuity. It is made available under a CC-BY-NC-ND 4.0 International license .

21-Marui VC, Souto MLS, Rovai ES, Romito GA, Chambrone L, Pannuti CM. Efficacy of preprocedural mouthrinses in the reduction of microorganisms in aerosol: A systematic review. J Am Dent Assoc. 2019;150(12):1015-1026.e1. doi:10.1016/j.adaj.2019.06.024

22-Logothetis DD, Martinez-Welles JM. Reducing bacterial aerosol contamination with a chlorhexidine gluconate pre-rinse. J Am Dent Assoc. 1995;126(12):1634-1639. doi:10.14219/jada.archive.1995.0111

23-Wood A, Payne D. The action of three antiseptics/disinfectants against enveloped and nonenveloped viruses. J Hosp Infect. 1998;38(4):283-295. doi:10.1016/s01956701(98)90077-9

24-Sneader W. Drug discovery: a history. New York: Wiley; 2005. p. 68.

25-Wutzler P, Sauerbrei A, Klöcking R, Brögmann B, Reimer K. Virucidal activity and cytotoxicity of the liposomal formulation of povidone-iodine. Antiviral Res. 2002;54(2):89-97. doi:10.1016/s0166-3542(01)00213-3

26-Kawana R, Kitamura T, Nakagomi O, et al. Inactivation of human viruses by povidoneiodine in comparison with other antiseptics. Dermatology. 1997;195 Suppl 2:29-35. doi:10.1159/000246027

27-Kariwa H, Fujii N, Takashima I. Inactivation of SARS coronavirus by means of povidoneiodine, physical conditions and chemical reagents. Dermatology. 2006;212 Suppl 1(Suppl 1):119-123. doi:10.1159/000089211

28-Eggers M, Eickmann M, Kowalski K, Zorn J, Reimer K. Povidone-iodine hand wash and hand rub products demonstrated excellent in vitro virucidal efficacy against Ebola virus and modified vaccinia virus Ankara, the new European test virus for enveloped viruses. BMC Infect Dis. 2015;15:375. Published 2015 Sep 17. doi:10.1186/s12879-0151111-9

29-Eggers M, Eickmann M, Zorn J. Rapid and Effective Virucidal Activity of Povidone-Iodine Products Against Middle East Respiratory Syndrome Coronavirus (MERS-CoV) and Modified Vaccinia Virus Ankara (MVA). Infect Dis Ther. 2015;4(4):491-501. doi:10.1007/s40121-015-0091-9 
medRxiv preprint doi: https://doi.org/10.1101/2021.03.07.21252302; this version posted March 17, 2021. The copyright holder for this preprint (which was not certified by peer review) is the author/funder, who has granted medRxiv a license to display the preprint in perpetuity.

It is made available under a CC-BY-NC-ND 4.0 International license .

30-Committee for the Japanese Respiratory Society Guidelines in Management of Respiratory. Prevention of hospital-acquired pneumonia (strategies for prevention of hospital-acquired infections). Respirology. 2004;9 Suppl 1:S48-S50. doi:10.1111/j.14401843.2003.00552.x

31-Duchamp MB, Casalegno JS, Gillet Y, et al. Pandemic A(H1N1)2009 influenza virus detection by real time RT-PCR: is viral quantification useful?. Clin Microbiol Infect. 2010;16(4):317-321. doi:10.1111/j.1469-0691.2010.03169.x

32-Nicola M, O'Neill N, Sohrabi C, Khan M, Agha M, Agha R. Evidence based management guideline for the COVID-19 pandemic - Review article. Int J Surg. 2020;77:206-216. doi:10.1016/j.ijsu.2020.04.001

33-American Dental Association (ADA) (2020) ADA adds frequently asked questions from dentists to coronavirus resources. ADA American Dental Association. Available at: https://www.ada.org/ en/publications/ada-news/2020-archive/march/ada-addsfrequentlyasked-questions-from-dentists-to-coronavirus-resources 20.

34-Institut der Deutschen Zahnärzte (IDZ) (2020) System von Standardvorgehensweisen für Zahnarztpraxen während der Coronavirus-Pandemie. Available at: https://www.idz.institute/ fileadmin/Content/PublikationenPDF/Weitere_Dokumente/IDZ_SARS-CoV-2_Standardvorgehensweise_ZAP_2020-0424.pdf.

35-Association Dentaire Française (2020). COVID-19 Guide pratique à partir des recommandations d'experts validées. Available at: https://www.fdiworlddental.org/sites/default/files/media/documents/covid19 guide_pratique_a_partir_des_recommandations_dexperts_validees.pdf.

36-Ather A, Patel B, Ruparel NB, Diogenes A, Hargreaves KM. Coronavirus Disease 19 (COVID-19): Implications for Clinical Dental Care. J Endod. 2020;46(5):584-595. doi:10.1016/j.joen.2020.03.008

37-Izzetti R, Nisi M, Gabriele M, Graziani F. COVID-19 Transmission in Dental Practice: Brief Review of Preventive Measures in Italy. J Dent Res. 2020;99(9):1030-1038. doi:10.1177/0022034520920580 
medRxiv preprint doi: https://doi.org/10.1101/2021.03.07.21252302; this version posted March 17, 2021. The copyright holder for this preprint (which was not certified by peer review) is the author/funder, who has granted medRxiv a license to display the preprint in perpetuity. It is made available under a CC-BY-NC-ND 4.0 International license .

38-Zimmermann M, Nkenke E. Approaches to the management of patients in oral and maxillofacial surgery during COVID-19 pandemic. J Craniomaxillofac Surg. 2020;48(5):521-526. doi:10.1016/j.jcms.2020.03.011

39-Meng L, Hua F, Bian Z. Coronavirus Disease 2019 (COVID-19): Emerging and Future Challenges for Dental and Oral Medicine. J Dent Res. 2020;99(5):481-487. doi:10.1177/0022034520914246

40-Diegritz C, Manhart J, Bücher K, et al. A detailed report on the measures taken in the Department of Conservative Dentistry and Periodontology in Munich at the beginning of the COVID-19 outbreak. Clin Oral Investig. 2020;24(8):2931-2941. doi:10.1007/s00784020-03440-z

41-Jamal M, Shah M, Almarzooqi SH, et al. Overview of transnational recommendations for COVID-19 transmission control in dental care settings [published online ahead of print, 2020 May 19]. Oral Dis. 2020;10.1111/odi.13431. doi:10.1111/odi.13431

42-Xu C, Wang A, Hoskin ER, et al. Differential effects of antiseptic mouth rinses on SARSCoV-2 infectivity in vitro. Preprint. bioRxiv. 2020;2020.12.01.405662. Published 2020 Dec 1. doi:10.1101/2020.12.01.405662

43-Li Y, Yao L, Li J, et al. Stability issues of RT-PCR testing of SARS-CoV-2 for hospitalized patients clinically diagnosed with COVID-19. J Med Virol. 2020;92(7):903-908. doi:10.1002/jmv.25786

44-Sakpal TV. Sample size estimation in clinical trial. Perspect Clin Res. 2010;1(2):67-69.

45-Yu C, Li L, Tuersun Y, et al. Oropharyngeal Secretion as Alternative for SARS-CoV-2 Detection. J Dent Res. 2020;99(10):1199-1205. doi:10.1177/0022034520940292

46-Williams E, Bond K, Zhang B, Putland M, Williamson DA. Saliva as a Noninvasive Specimen for Detection of SARS-CoV-2. J Clin Microbiol. 2020;58(8):e00776-20. Published 2020 Jul 23. doi:10.1128/JCM.00776-20 
medRxiv preprint doi: https://doi.org/10.1101/2021.03.07.21252302; this version posted March 17, 2021. The copyright holder for this preprint (which was not certified by peer review) is the author/funder, who has granted medRxiv a license to display the preprint in perpetuity. It is made available under a CC-BY-NC-ND 4.0 International license .

47-McCormick-Baw C, Morgan K, Gaffney D, et al. Saliva as an Alternate Specimen Source for Detection of SARS-CoV-2 in Symptomatic Patients Using Cepheid Xpert Xpress SARS-CoV-2. J Clin Microbiol. 2020;58(8):e01109-20. Published 2020 Jul 23. doi:10.1128/JCM.01109-20

48-Martínez Lamas L, Diz Dios P, Pérez Rodríguez MT, et al. Is povidone iodine mouthwash effective against SARS-CoV-2? First in vivo tests [published online ahead of print, 2020 Jul 2]. Oral Dis. 2020;10.1111/odi.13526. doi:10.1111/odi.13526

49-Frank S, Capriotti J, Brown SM, Tessema B. Povidone-Iodine Use in Sinonasal and Oral Cavities: A Review of Safety in the COVID-19 Era. Ear Nose Throat J. 2020;99(9):586593. doi:10.1177/0145561320932318

50-Mady LJ, Kubik MW, Baddour K, Snyderman CH, Rowan NR. Consideration of povidoneiodine as a public health intervention for COVID-19: Utilization as "Personal Protective Equipment" for frontline providers exposed in high-risk head and neck and skull base oncology care. Oral Oncol. 2020;105:104724. doi:10.1016/j.oraloncology.2020.104724

51-Suresh V, Sharma S, Aggarwal A. Preanesthetic Povidone-Iodine gargles for patients with COVID-19. J Clin Anesth. 2020;67:110035. doi:10.1016/j.jclinane.2020.110035

52-Bidra AS, Pelletier JS, Westover JB, Frank S, Brown SM, Tessema B. Rapid In-Vitro Inactivation of Severe Acute Respiratory Syndrome Coronavirus 2 (SARS-CoV-2) Using Povidone-Iodine Oral Antiseptic Rinse. J Prosthodont. 2020;29(6):529-533. doi:10.1111/jopr.13209

53-Pelletier JS, Tessema B, Frank S, Westover JB, Brown SM, Capriotti JA. Efficacy of Povidone-Iodine Nasal and Oral Antiseptic Preparations Against Severe Acute Respiratory Syndrome-Coronavirus 2 (SARS-CoV-2) [published online ahead of print, 2020 Sep 21] [published correction appears in Ear Nose Throat J. 2020 Dec 8;:145561320977784]. Ear Nose Throat J. 2020;145561320957237. doi:10.1177/0145561320957237

54-Chorney SR, Rizzi MD, Dedhia K. Considerations for povidone-iodine antisepsis in pediatric nasal and pharyngeal surgery during the COVID-19 pandemic. Am J Otolaryngol. 2020;41(6):102737. doi:10.1016/j.amjoto.2020.102737 
medRxiv preprint doi: https://doi.org/10.1101/2021.03.07.21252302; this version posted March 17, 2021. The copyright holder for this preprint (which was not certified by peer review) is the author/funder, who has granted medRxiv a license to display the preprint in perpetuity. It is made available under a CC-BY-NC-ND 4.0 International license.

55-Yoon JG, Yoon J, Song JY, et al. Clinical Significance of a High SARS-CoV-2 Viral Load in the Saliva. J Korean Med Sci. 2020;35(20):e195. Published 2020 May 25. doi:10.3346/jkms.2020.35.e195

56-Meister TL, Brüggemann Y, Todt D, et al. Virucidal Efficacy of Different Oral Rinses Against Severe Acute Respiratory Syndrome Coronavirus 2.J Infect Dis. 2020;222(8):1289-1292. doi:10.1093/infdis/jiaa471

57-Herrera D, Serrano J, Roldán S, Sanz M. Is the oral cavity relevant in SARS-CoV-2 pandemic?. Clin Oral Investig. 2020;24(8):2925-2930. doi:10.1007/s00784-020-03413-2 